$\sqrt{B}$

J. Bio-Sci. 24: 11-18, 2016

ISSN 1023-8654

http://www.banglajol.info/index.php/JBS/index

\title{
PHYTOCHEMICAL SCREENING OF SYZYGIUM CUMINI (L.) EXTRACTS IN DIFFERENT SOLVENTS
}

\author{
M Hasanuzzaman ${ }^{1}$, W Islam $^{1 *}$ and MB Islam ${ }^{2}$ \\ 1Institute of Biological Sciences, University of Rajshahi, Bangladesh \\ 2 Bangladesh Council of Scientific and Industrial Research Laboratories, Rajshahi, Bangladesh
}

\begin{abstract}
Phytochemical screening of the secondary metabolites was performed with acetone, chloroform, methanol and n-hexane extracts of the leaves, roots, stem bark and seeds of the plant Syzygium cumini (Linn.) and were detected using various tests for identifying the isolated components. Acetone extract of the leaves showed the presence glycosides, phenols, proteins, resins and saponins while the stem bark extract showed the presence of alkaloids, flavonoids, glycosides, phenols, proteins, resins and saponins. All the above constituents except saponins were detected in the root extract. The seed extract contains alkaloids, carbohydrates, phenols, proteins and tannins. Chloroform extract of the leaves showed the presence of alkaloids, proteins and steroids while root extract contains alkaloids and steroids and that of seed extract alkaloids, carbohydrates, phenols, proteins and tannins, however, alkaloids and tannins were found in the stem bark extract. Methanol extract of the leaves and stem bark showed the presence of alkaloids, carbohydrates, flavonoids, glycosides, phenols, resins, saponins, steroids and tannins while the root extracts contain all the above constituents along with proteins. $\mathrm{N}$ hexane extract of the leaves contain only alkaloids, roots contain alkaloids and resins and that of seeds contain carbohydrates and proteins while alkaloids, proteins and tannins were found in stem bark extract. The present findings reveal the presence of various medicinally important phytochemicals from the plant S. cumini extracts may have application in traditional system of medicine to cure various ailments.
\end{abstract}

Key words: Extracts, phytochemical, solvents, Syzygium cumini

\section{Introduction}

Plants are the chemical factories of nature, producing many chemicals, some of which have medicinal and pesticidal properties. Recently, in different parts of the world, attention has been paid towards exploitation of higher plant products as novel chemotherapeutants. The plant components are non phytotoxicity, systemicity, easy biodegradability and stimulatory in nature. Plant products possess the potentials used in pest management (Dubey et al. 2008). Phytochemicals are naturally occurring in the medicinal plants that have defense mechanism and protect the plant from various diseases (Krishnaiah et al. 2007). The nonnutritive plant chemicals have protective or disease preventive properties. Plant produces these chemicals to protect itself but recent research demonstrates that many phytochemicals can protect humans against diseases. Plants are rich in a wide variety of secondary metabolites, such as tannins, terpenoids, alkaloids, and flavonoids, which have been found in vitro to have antimicrobial properties (Sibanda and Okoh 2007). The term qualitative phytochemical analysis refers to the procedures involved in establishing and proving the identity of the phytochemical constituents present in the crude plant extract. The pharmacological actions of crude drugs are determined by the nature of their constituents present there in the phytochemicals.

*Author for correspondence: mwislam2001@yahoo.com 
Syzygium cumini L. is a very common, large evergreen tree of the Indian Subcontinent commonly known as Jamun, belongs to the Myrtaceae family. The original home of S. cumini is India or the East Indies. It is found in Thailand, Philippines, Madagascar, West Indies, East and West Africa and some subtropical regions including Florida, California, Algeria and Israel.

The major phytoconstituents are reported to contain vitamin C, gallic acid, tannins, anthocyanins, cyanidin, petunidin, malvidinglucoside and other components (Annonymous 1976, Martinez and Valle 1981). Preliminary phytochemical analysis also showed the presence of phenols, terpenoids, tannins, saponins, phytosterols, carbohydrates, flavonoids, amino acids in the stem bark of S. cumini (Kuncha et al. 2012). The stem bark of S. cumini also contains butulinic acid, $\beta$-sitosterol, friedelin, epi-friedelanol (Annonymous 1976). It also contains new esters of epifriedelanol (eugenin), D-glucoside, kaempterol-3-O-glucoside, quercetin, myricetin, astragalin and gallic acid (Bhargava et al. 1974).

The plant derived compounds have been utilized by the humans from time immemorial in different sectors of life, including public health and pest management. The test plant is also a native to Bangladesh and is easily available. The seeds of S. cumini are used as astringent and diuretic (Bhatia and Bajaj 1975). They have hypoglycaemic (Chopra et al. 1958, Mahapatra et al.1985, Stanely et al. 1998a), anti-inflammatory (Chaudhari et al. 1990), antipyretic (Ghosh et al. 1985), psychopharmacological (Chakraborty et al. 1985), hypolipidaemic (Stanely and Menon 1997), and antioxidant (Stanely and Menon 1998b, Banerjee et al. 2005, Bushra et al. 2007) activities. Hence, the present study was made to investigate the phytochemical screening of the S. cumini leaves, root, seeds and stem bark extracted in different solvents.

\section{Materials and Methods}

\section{Plant collection and identification}

The leaves, roots, seed and stem bark of S. cumini were collected in fresh condition during the season of maturity June-July, 2011 from Rajshahi University Campus and identified by taxonomical section, Department of Botany, University of Rajshahi. A voucher specimen has been deposited in the herbarium for future reference.

\section{Preparation of plant extracts}

The plant materials were separately powdered in a grinder machine. The powdered materials were weighed and placed in separate conical flasks to add sufficient amount of chloroform $(500 \mathrm{~g} \times 1500 \mathrm{ml} \times 3$ times followed by filtration through Whatman 1 filter paper at interval of $24 \mathrm{~h}$ for 3 times in the same collection flask) to yield the first extracts of the leaves, roots, seeds and stem bark separately. The output extracts were poured in to glass vials and reserved in a refrigerator at $4^{\circ} \mathrm{C}$ with proper labeling. For each of the samples four solvents, acetone, chloroform, methanol and n-hexane were used successively.

\section{Preparation of stock solution}

A piece of clean sodium is placed in a fusion tube. The lower part of the tube is heated until the sodium melts down. Then a few milligrams of a particular extract is added and heated until the bottom of the tube become dull red. It was dropped into a small mortar containing $15 \mathrm{ml}$ distilled water. The tube broken up with a pestle and the solution was then filtered and the filtrate was used as the stock solution. The stock solution was then used for the specific test described below: 


\section{Test of alkaloids (Mayer's test)}

Mercuric chloride $(1.36 \mathrm{gm})$ was dissolved in $60 \mathrm{ml}$ and $5 \mathrm{gm}$ of potassium iodide was dissolved in $10 \mathrm{ml}$ of distilled water respectively. These two preparations were mixed and diluted to $100 \mathrm{ml}$ using distilled water. 1 $\mathrm{ml}$ of acidic aqueous solution of samples and few drops of reagent was added. Formation of white or pale precipitate showed the presence of alkaloids.

\section{Test of carbohydrates (Molisch's test)}

In a test tube containing $2 \mathrm{ml}$ of aqueous extract of the samples, 2 drops of freshly prepared $20 \%$ alcoholic solution of alpha-naphthol and mixed, poured $2 \mathrm{ml}$ of concentrated sulfuric acid so as to form a layer below the mixture. Appearance of produce a red violet ring which disappears on the addition of an excess of alkali solution indicated the presence of carbohydrates.

\section{Test of flavonoids}

In a test tube containing $0.5 \mathrm{ml}$ of alcoholic extract of the samples, 5 to 10 drops of diluted $\mathrm{HCl}$ and small amount of $\mathrm{Zn}$ or Mg were added and the solution was boiled for few minutes. Appearance of reddish pink or dirty brown color indicated the presence of flavonoids.

\section{Test of glycosides}

A small amount of extracts were dissolved in $1 \mathrm{ml}$ water and then aqueous sodium hydroxide was added. Formation of a yellow color indicated the presence of glycosides.

\section{Test of steroids (Salkowski's test)}

About $100 \mathrm{mg}$ of dried extract was dissolved in $2 \mathrm{ml}$ of chloroform. Sulphuric acid was carefully added to form a lower layer. A reddish brown color at the interface was an indicative of the presence of steroidal ring.

\section{Test of saponins}

A drop of sodium bicarbonate was added in a test tube containing about $50 \mathrm{ml}$ of an extract. The mixture was shaken vigorously and kept for 3 minutes. A honey comb like froth was formed and it showed the presence of saponins.

\section{Test of resins}

Two $\mathrm{ml}$ of chloroform or ethanolic extract was added in 5 to $10 \mathrm{ml}$ of acetic anhydrite and dissolved by gentle heating after cooling, $0.5 \mathrm{ml}$ of $\mathrm{H}_{2} \mathrm{SO}_{4}$ was added. Bright purple color was produced to indicate the presence of resins.

\section{Test of phenols (Ferric chloride test)}

One $\mathrm{ml}$ of alcoholic solution of extract, $2 \mathrm{ml}$ of distilled water followed by a few drops of $10 \%$ aqueous ferric chloride solution was added. Formation of blue or green color indicated the presence of phenols.

\section{Test of tannins (Lead acetate test)}

A few drops of $1 \%$ solution of lead acetate was added. In a test tube containing about $5 \mathrm{ml}$ of an aqueous extract. Formation of a yellow or red precipitate indicate the presence of tannins.

\section{Test of proteins (Biuret's test)}

One $1 \mathrm{ml}$ of hot extract was added 5-8 drops of 10\% (W/V) copper sulphate solution in a test tube. A red or violet color indicated the presence of protein. 


\section{Results}

The phytochemical screening was performed with the acetone, chloroform, methanol and $n$-hexane extracts of the leaves of S. cumini. Glycosides, phenols, proteins, steroids and tannins were detected in the acetone extract; alkaloids, proteins and steroids from chloroform extract; alkaloids, carbohydrates, flavonoids, glycosides, phenols, resins, saponins; and tannins from the methanol extract; and only the alkaloids were detected from the n-hexane extract (Table 1).

Table 1. Phytochemical screening of S. cumini leaf extracts.

\begin{tabular}{lcccc}
\hline Phytoconstituents & n-Hexane & Acetone & Chloroform & Methanol \\
\hline Alkaloids & + & + & + & + \\
Carbohydrates & - & - & - & + \\
Flavonoids & - & - & - & + \\
Glycosides & - & + & - & + \\
Phenols & - & + & - & + \\
Proteins & - & - & - & + \\
Resins & - & + & + & + \\
Saponins & - & + & + & + \\
Steroids & - & & + \\
Tannins & - & & +
\end{tabular}

't' = Presence; '-'= Absence

Preliminary phytochemical analysis of the stem bark of $S$. cumini showed the presence of flavonoids, glycosides, phenol, proteins, resins and saponins in the acetone extract; alkaloids, carbohydrates, flavonoids, glycosides, phenols, resins, saponins, steroids and tannins were recorded in the methanol extract; only alkaloids and tannins were detected in the chloroform extract wheras alkaloids, proteins and tannins were detected in the n-hexane extract (Table 2).

Table 2. Phytochemical screening of $S$. cumini stem bark extracts.

\begin{tabular}{lcccc}
\hline Phyto-constituents & n-Hexane & Acetone & Chloroform & Methanol \\
\hline Alkaloids & + & + & + & + \\
Carbohydrates & - & - & - & + \\
Flavonoids & - & + & - & + \\
Glycosides & - & + & - & + \\
Phenols & - & + & - & + \\
Proteins & + & + & - & + \\
Resins & - & + & - & + \\
Saponins & - & - & - & + \\
Steroids & - & - & + & + \\
Tannins & + & & & \\
\hline
\end{tabular}

't' = Presence; '-'= Absence 
In the root extract all the tested phytoconstituents were detected in the methanol extract; alkaloids, carbohydrates, phenol, proteins and tannins were detected in the acetone and chloroform extracts, but only carbohydrates and proteins were detected from n-hexane extract (Table 3).

Table 3. Phytochemical screening of $S$. cumini root extracts.

\begin{tabular}{lcccc}
\hline Phyto-constituents & n-Hexane & Acetone & Chloroform & Methanol \\
\hline Alkaloids & + & + & + & + \\
Carbohydrates & - & + & - & + \\
Flavonoids & - & + & - & + \\
Glycosides & - & + & - & + \\
Phenols & - & + & - & + \\
Proteins & - & - & - & + \\
Resins & + & + & + & + \\
Saponins & - & + & - & + \\
Steroids & - & & & + \\
Tannins & - & + & +
\end{tabular}

't' = Presence; '-'= Absence

Screening of seed extracts of S. cumini showed that alkaloids, flavonoids, phenols, proteins, resins and tannins were detected in methanol extract; alkaloids, carbohydrates, phenols, proteins and tannins were found in the acetone and chloroform extracts whereas only carbohydrates and proteins were detected in the n-hexane extracts (Table 4).

Table 4. Phytochemical screening of S. cumini seed extracts.

\begin{tabular}{lrrrr}
\hline Phyto-constitutents & n-Hexane & Acetone & Chloroform & Methanol \\
\hline Alkaloids & - & + & + & + \\
Carbohydrates & + & - & - & + \\
Flavonoids & - & - & - & + \\
Glycosides & - & + & + & + \\
Phenols & - & + & - & + \\
Proteins & + & - & - & + \\
Resins & - & - & - & - \\
Saponins & - & - & + & + \\
Steroids & - & + & & + \\
Tannins & - & & +
\end{tabular}

't' = Presence; '-'= Absence 


\section{Discussion}

The extracts of $S$. cumini in different solvents revealed the presence of phytochemicals such as alkaloids, carbohydrates, flavonoids, glycosides, phenol, resins, saponins, tannins and steroids which are summarized in Tables 1-4. The phytochemicals detected are known to have beneficial importance in medical sciences. Alkaloids are the secondary metabolites of plants. They are internal constituents of plants so called as biomolecules. Chemically they contain nitrogen and alkaline in nature. They are found in plant organs like leaves, stem, bark, roots, etc. They are used as medicines in serious disorders like heart-failure, cancer, blood pressure, etc., Euphoric and addicting drugs and pesticides or insect repellents (Nobori et al. 1994). The carbohydrates produced by plants are important source of energy transportation for animals. It is a biomolecules. Carbohydrate derivatives are involved in reproduction, the immune system, the development of disease and blood clotting. Flavonoides are a group of plant metabolites thought to provide health benefits through cell signaling pathways and antioxidant effects and used reduced risk of cancer, heart disease, asthma and stroke (Aiyelaagbe and Osamudiamen 2009). Glycosides is also a molecule and used as atrial flutter, atrial fibrillation, paroxysmal tachycardia, congestive heart failure (Nyarko and Addy 1990).

The total polyphenol contents in methanolic and aqueous fractions of $S$. cumini leaves were found to be 180 and $94 \mathrm{mg} / \mathrm{g}$, respectively, using the Folin-Ciocalteu and acid gallic as standard (Kaneria et al. 2009). An infusion made from the skin of the ripe fruits of $S$. cumini showed the presence of around $100 \mathrm{mg} / \mathrm{g}$ of phenolics (Banerjee et al. 2005). Many parts of $S$. cumini including seeds have significant polyphenolic content and the antioxidant properties of these compounds are frequently associated with the antidiabetic effect of many plant species (Sabu et al. 2002, Hanamura et al. 2005).

The resin acts as a bandage protecting the plant from invading insects and pathogens. Plant resins are valued for the production of varnishes, adhesives, and food glozing agents. Saponin seems to reduce blood cholesterol levels, reduce the risk of cancer and stimulate immune system. It is also known to have antifungal properties (Haslem 1989). Ukoha et al. (2011) found tannins bind to proline rice protein and interfere with protein synthesis. It also exhibit antiviral, antibacterial and anti-tumor activities. Steroids are antiinflammatory, immune-modulating (William et al. 2014). The present findings indicate that phytochemical compounds are the bioactive constituents and this plant is proving to be a valuable reservoir of bioactive compounds of potential health benefits.

\section{Acknowledgement}

This research work has been done with the financial assistance of the fund approved as project (Bio12/2016) by the University Grants Commission of Bangladesh.

\section{References}

Aiyelaagbe $\mathrm{OO}$ and Osamudiamen PM (2009). Phytochemical screening for active compounds in Mangifera indica, Asian Journal of Plant Science and Research 2: 11-13.

Annon (1976). The Wealth of India: Raw materials, CSIR, New Delhi 10: 100-106.

Banerjee A, Dasgupta N and Bratati D (2005). In vitro study of antioxidant activity of Syzygium cumini fruit, Food Chemistry 90: 727-733. 
Bhatia IS and Bajaj KL (1975). Chemical constituents of the seeds and bark of Syzygium cumini, Planta Medica 28 : 346-52.

Bhargava KK, Dayar R and Sheshardi TR (1974). Chemical components of Eugenia jumbolona stem barks, Current Science 43: 645-646.

Bushra S, Farooq A and Roman P (2007). Antioxidant activity of phenolic components present in barks of Azadirachta indica, Terminalia arjuna, Acacia nilotica and Eugenia jambolana Lam trees, Food Chemistry 104: 1106-1114.

Chakraborty D, Chaudhuri AKN and Mahapatra PK (1985). Studies on psychopharmacological actions of Syzigium cumini Linn seed extract, IRCS Medical Science Biochemistry 13: 746-747.

Chaudhuri AKN, Pal S, Gomes A and Bhattacharya S (1990). Antiinflammatory and related actions of Syzygium cumini seed extract, Phytotheraphy Research 4: 5-10.

Chopra RN, Chopra IC, Handa KL and Kapur LD (1958). Indigenous Drugs of India, 2nd eds. UC Dhar and Sons Pvt. Ltd., Calcutta, 686 pp.

Dubey NK, Srivastava B and Kumar A (2008). Current status of plant products as botanical pesticides in storage pest management, Journal of Biopesticides 1: 182-186.

Ghosh KD, Chakraborty GK, Chatterjee AKN, Chaudhury and Pal M (1985). Studies on anti-inflammatory and antipyretic activities of Syzygium cumini Linn seeds, IRCS Medical Science Biochemistry 13: 340-341.

Hanamura T, Hagiwara T and Kawagishi H (2005). Structural and functional characterization of polyphenols isolated from acerola (Malpighia emarginata DC.) fruit, Bioscience Biotechnology Biochemistry 69: 280-286.

Haslem E (1989). Plant polyphenols vegetable tannins revised: chemistry and pharmacology of natural products (Cambridge University Press), 169 pp.

Kaneria M, Chanda S, Baravalia Y and Vaghasiya $Y$ (2009). Determination of antibacterial and antioxidant potential of some medicinal plants from Saurashtra Region, India, Indian Journal of Pharmaceutical Science 71: 406-412.

Krishnaiah D, Sarbatly R and Bono A (2007). Phytochemical antioxidants for health and medicine A move towards nature. Biotechnology Molecular Biology Reviews 1: 97-104.

Kuncha J, Ayyachami M and Mariapan M (2012). In vitro evaluation of nitric oxidescavenging activity of methanolic and aqueous extract of Syzygium cumini, International Journal of Pharmaceutical Science and Research 3: 615-619.

Mahapatra PK, Pal M, Chaudhuri AKN, Chakraborty D and Basu A (1985). Preliminary studies on glycaemic effect of Syzigium cumini seeds. IRCS Medical Science and Biochemistry 13: 631-632.

Martinez SB and Del Valle MJ (1981). Storage stability and sensory quality of duhat Syzygium cumini L. anthocyanins as food colorant, Uttar Pradesh Home Economics Journal 9: 1.

Nobori T, Miurak K, Wu DJ, Takabayashik LA and Carson DA (1994). Deletion of cyclin dependent kinnase 4 inhibitor gene in multiple human cancers. Nature 46: 753-756.

Nyarko AA and Addy ME (1990). Effects of aquous extract of Adenia cissapeloides on blood pressure and serum analyte of hypertensive patients, Phytotherapy Research 4 (1): 25-28.

Sabu MC, Smitha K and Kuttan R (2002). Anti-diabetic activity of green tea polyphenols and their role in reducing oxidative stress in experimental diabetes, Journal of Ethnopharmacology 83: 109-116.

Sibanda T and Okoh Al (2007). The challenges of overcoming antibiotic resistance: Plant extracts as potential sources of antimicrobial and resistance modifying agents, African Journal of Biotechnology 6(25): 2886-2896.

Stanely MPP and Menon VP (1997). Hypolipidaemic effect of Syzygium cumini (Jamun) seeds in alloxan diabetic rats, Medical Science Research 25: 819-821. 
Stanely MPP, Menon VP and Pari L (1998a). Hypoglycaemic activity of Syzigium cumini; effect on lipid peroxidation in alloxan diabetic rats, Journal of Ethnopharmacologh 61: 1-7.

Stanely MPP and Menon VP (1998b). Effect of Syzigium cumini in plasma antioxidants on alloxan-induced diabetes in rats, Journal of Clinical Biochemistry and Neutral 25: 81-86.

Ukoha PO, Cemaluk EAC, Namdi OL and Madus EP (2011). Tannins and other phytochemical of the Samanaea saman pods and their antimicrobial activities. African Journal of Pure and Applied Chemistry 5 (8): 237-244.

William Ericson-Neilsen MD and Kaye AD (2014). Steroids: Pharmacology, complications, and practice delivery issues, The Ochsner Journal 14 (2): 203-207. 